\title{
PENGEMBANGAN TECHNOLOGY ACCEPTANCE MODEL (TAM) SEBAGAI UPAYA PEMBERDAYAAN MASYARAKAT MENUJU MASYARAKAT INFORMASI
}

\author{
Oliver Samuel Simanjuntak \\ Jurusan Teknik Informatika UPN "Veteran" Yogyakarta \\ JI. Babarsari 2 Tambakbayan 55281 Telp (0274) 485323 \\ email: oliver.simanjuntak@upnyk.ac.id
}

\begin{abstract}
Development of the Technology Acceptance Model (TAM) describes that there are dominant factors affecting the integration of information and communication technology (ICT) in society. This paper described the development of TAM in the context of the implementation of community development towards an information society. Implementation of empowerment facilitators conducted with the community. Implementation of empowerment aims to build positive perceptions of the benefits and convenience of ICT in society. Perceptions will positively affect the willingness of communities to utilize ICT. Furthermore, the willingness to utilize ICTs will influence the awareness and public demand for information as a source of strength. Communities that utilize ICT in order to satisfy the high demand for information is called information society.
\end{abstract}

Keywords: TAM, community empowerment, community information, facilitator.

Pengembangan Technology Acceptance Model (TAM) mendeskripsikan terdapat faktorfaktor yang secara dominan mempengaruhi integrasi teknologi informasi dan komunikasi (TIK) di masyarakat. Pada penelitian ini akan dijelaskan pengembangan TAM sebagai upaya pemberdayaan masyarakat menuju masyarakat informasi. Upaya pemberdayaan memberi landasan secara jelas dukungan media komunikasi dan pelaksanaan pemberdayaan. Pelaksanaan pemberdayaan dilaksanakan fasilitator bersama masyarakat. Pelaksanaan pemberdayaan bertujuan membangun persepsi positif terhadap manfaat dan kemudahan TIK di masyarakat. Persepsi positif akan mempengaruhi kemauan masyarakat mendayagunakan TIK. Selanjutnya kemauan mendayagunakan TIK akan mempengaruhi kesadaran dan kebutuhan masyarakat terhadap informasi sebagai sumber kekuatan. Masyarakat yang mendayagunakan TIK dalam rangka pemuasan kebutuhan yang tinggi akan informasi disebut sebagai masyarakat informasi.

Kata-kunci: TAM, pemberdayaan masyarakat, masyarakat informasi, fasilitator.

\section{PENDAHULUAN}

Salah satu teori integrasi teknologi yang cukup populer adalah technology acceptance model (TAM). Pengembangan TAM mendeskripsikan terdapat dua faktor yang secara dominan mempengaruhi integrasi teknologi. Faktor pertama adalah persepsi pengguna terhadap manfaat teknologi. Sedangkan faktor kedua adalah persepsi pengguna terhadap kemudahan penggunaan teknologi. Kedua faktor tersebut mempengaruhi kemauan untuk memanfaatkan teknologi. Selanjutnya kemauan untuk memanfaatkan teknologi akan mempengaruhi penggunaan teknologi yang sesungguhnya.

Menurut Sharma dan Mochtar (2005), ketersediaan teknologi bagi masyarakat mencakup "includes not just the availability of content and applications but its affordability as well. The issue of usability is also relevant, given that $80 \%$ of Internet content is in English." Dari uraian tersebut, ketersediaan akses informasi/teknologi perlu juga mempertimbangkan ketersediaan, kondisi dan kebutuhan masyarakat setempat dalam mengakses informasi. Sebagai contoh adalah menyediakan konten di internet yang disesuaikan dengan bahasa masyarakat setempat.

Pengembangan TAM bertujuan untuk memberikan rekomendasi upaya pemberdayaan masyarakat menuju masyarakat informasi. Upaya pemberdayaan masyarakat berupaya meningkatkan persepsi masyarakat terhadap manfaat dan kemudahan pendayagunaan TIK. 
Upaya pemberdayaan memberi landasan secara jelas dukungan media komunikasi dan pelaksanaan pemberdayaan yang harus diambil fasilitator bilamana dihadapkan pada konteks yang berlaku di masyarakat. Media komunikasi bertujuan agar masyarakat dapat lebih mudah menerima dan memahami informasi dari fasilitator pemberdayaan. Dukungan media komunikasi berpengaruh dalam menumbuhkan persepsi positif masyarakat untuk mendayagunakan TIK. Dengan kesiapan dukungan media komunikasi maka pelaksanaan pemberdayaan masyarakat menuju masyarakat informasi dapat dimulai. Tahap pelaksanaan pemberdayaan masyarakat meliputi keseluruhan aktivitas yang dilaksanakan fasilitator bersama masyarakat.

Meningkatnya persepsi masyarakat terhadap pendayagunaan TIK diharapkan dapat berimplikasi mereduksi kesenjangan digital dan mewujudkan masyarakat yang berdaya terhadap informasi. Masyarakat informasi akan memiliki kesadaran dan kebutuhan terhadap informasi sebagai sumber kekuatan.

\section{TINJAUAN PUSTAKA}

\subsection{PEMBERDAYAAN MASYARAKAT MENUJU MASYARAKAT INFORMASI}

Pemberdayaan masyarakat menuju masyarakat informasi adalah upaya untuk memberi keperdayaan bagi masyarakat yang diarahkan dalam membentuk masyarakat informasi. Menurut Polyviou (2007, h. 3), masyarakat informasi adalah "a society characterised by a high level of information intensity in the everyday of most of its citizens, in most organizations and workplaces; by the use of common or compatible technology for a wide range of personal, social, educational, and business activities and by the ability to transmit and receive digital data rapidly between places irrespective of distance." Dari uraian ini diketahui bahwa masyarakat informasi merupakan masyarakat yang menggunakan TIK untuk mencukupi intensitas kebutuhannya yang tinggi akan informasi. Masyarakat informasi memiliki kesadaran dan kebutuhan terhadap informasi sebagai sumber kekuatan. Masyarakat informasi akan menggunakan informasi untuk terlibat dalam proses pembangunan yaitu mengambil keputusan yang baik bagi dirinya sendiri, bertindak secara kritis dalam upaya memperbaiki keadaan dan mengatasi masalahnya sendiri, mampu terlibat dalam proses-proses sosial dan politik termasuk dalam proses pengambilan keputusan publik yang dilakukan komunitasnya (Kadiman, 2006).

\subsection{FASILITATOR}

Fasilitator adalah sebuah peran agen pemberdayaan. Tugas pokok fasilitator adalah menyebarkan pikiran-pikirannya sehingga mampu mempengaruhi kehidupan kultural dan intelektual pada masyarakat. Fasilitator melakukan langkah-langkah inovatif dan terorganisir untuk mengarahkan kelompok masyarakat yang kemampuannya masih lemah agar lebih berdaya dan akhirnya mampu memperkuat kesejahteraannya (Wrihatnolo dan Dwidjowojoto, 2007, h. 202).

\subsection{TAM (TECHNOLOGY ACCEPTANCE MODEL)}

Berbagai penelitian dilakukan untuk memodelkan proses integrasi teknologi semenjak tahun 1980 -an. Beberapa model yang dibangun untuk menganalisis dan memahami faktor-faktor yang mempengaruhi diterimanya penggunaan teknologi komputer, di antaranya yang tercatat dalam berbagai literatur dan referensi hasil riset dibidang teknologi informasi. adalah seperti Theory of Reasoned Action (TRA), Theory of Planned Behaviour (TPB), dan Technology Acceptance Model (TAM).

Model TAM sebenarnya diadopsi dari model TRA yaitu teori tindakan yang beralasan dengan satu premis bahwa reaksi dan persepsi seseorang terhadap sesuatu hal, akan menentukan sikap dan perilaku orang tersebut. Reaksi dan persepsi pengguna Teknologi Informasi (TI) akan mempengaruhi sikapnya dalam penerimaan terhadap teknologi tersebut. Salah satu faktor yang dapat mempengaruhinya adalah persepsi pengguna terhadap kemanfaatan dan kemudahan penggunaan TI sebagai suatu tindakan yang beralasan dalam konteks pengguna teknologi, sehingga alas an seseorang dalam melihat manfaat dan kemudahan penggunaan TI menjadikan tindakan/perilaku orang tersebut sebagai tolok ukur dalam penerimaan sebuah teknologi. Secara sederhana TAM dapat digambarkan dalam Gambar 1. 


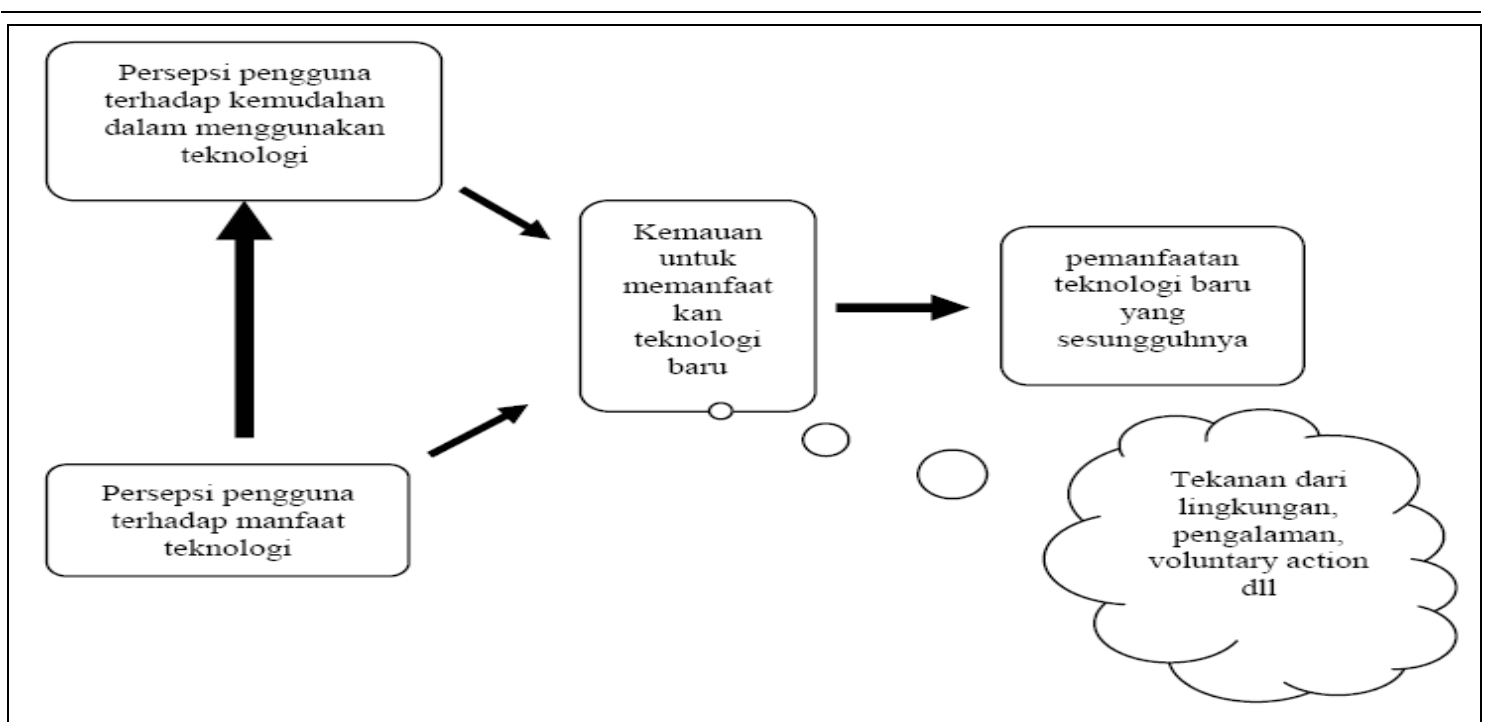

Gambar 1. Konsep Technology Acceptance Model (Wijaya, 2006)

Persepsi pengguna terhadap manfaat teknologi dapat diukur dari beberapa faktor sebagai berikut (Wijaya, 2006):

- Penggunaan teknologi dapat meningkatkan produktivitas pengguna.

- Penggunaan teknologi dapat meningkatkan kinerja pengguna.

- Penggunaan teknologi dapat meningkatkan efisiensi proses yang dilakukan pengguna.

Faktor-faktor diatas akan mempengaruhi persepsi pengguna terhadap manfaat teknologi. Pada umumnya penguna teknologi akan memiliki persepsi positif terhadap teknologi yang disediakan. Persepsi negatif akan muncul sebagai dampak dari penggunaan teknologi tersebut. Artinya persepsi negatif berkembang setelah pengguna pernah mencoba teknologi tersebut atau pengguna berpengalaman buruk terhadap penggunaan teknologi tersebut. Pengalaman buruk dapat berupa pengalaman menggunakan teknologi yang sejenis ataupun pengalaman setelah menggunakan teknologi yang disediakan.

Faktor penyebab pengalaman sebenarnya berkaitan erat dengan faktor kedua dari TAM yaitu persepsi pengguna terhadap kemudahan dalam menggunakan teknologi. Persepsi pengguna terhadap kemudahan dalam menggunakan teknologi dipengaruhi beberapa faktor, yaitu (Wijaya, 2006):

- Faktor pertama berfokus pada teknologi itu sendiri misalnya pengalaman pengguna terhadap penggunana teknologi yang sejenis. Pengalaman baik pengguna akan teknologi sejenis akan mempengaruhi persepsi pengguna terhadap teknologi baru yang disediakan, begitu pula sebaliknya.

- Faktor kedua adalah reputasi akan teknologi tersebut yang diperoleh oleh pengguna. Reputasi yang baik yang didengar oleh pengguna akan mendorong keyakinan penguna akan kemudahan penggunaan teknologi tersebut,demikian pula sebaliknya. Teknologi yang dimaksud bukan hanya teknologi yang akan diadopsi tetapi juga teknologi lain yang sejenis dengan teknologi yang akan diadopsi.

- Faktor ketiga yang mempengaruhi persepsi pengguna terhadap kemudahan menggunakan teknologi adalah tersedianya mekanisme support yang handal. Mekanisme support yang terpercaya akan mempengaruhi kepercayaan pengguna akan kemudahan teknologi misalnya pengguna merasa yakin bahwa terdapat mekanisme support yang handal jika kesulitan menggunakan teknologi maka mendorong persepsi pengguna kearah lebih positif.

Beberapa faktor dibawah ini dapat digunakan untuk mengukur persepsi pengguna terhadap kemudahan menggunakan sistem (Wijaya, 2006):

- Menggunakan sistem tidaklah menyulitkan pengguna.

- Pengguna merasa yakin bahwa mudah untuk mengerjakan apa yang diperlukan dengan sistem yang tersedia.

- Pengguna merasa yakin bahwa belajar menggunakan teknologi tidaklah memerlukan usaha yang keras. 
Berdasarkan hasil penelitian maka dapat diterapkan upaya-upaya yang dapat dilakukan untuk memperbaiki persepsi pengguna. Upaya-upaya yang dapat dilakukan untuk memperbaiki persepsi pengguna, yaitu (Wijaya, 2006).:

- Upaya membangun persepsi positif terhadap manfaat teknologi. Upaya membangun persepsi positif terhadap manfaat teknologi adalah sebagai berikut:

- Jika teknologi baru merupakan upgrade dari cara tradisional/teknologi lama maka dilakukan upaya penjelasan bahwa cara tradisional/teknologi lama sudah tidak dapat memenuhi/mempercepat pencapaian kebutuhan. Selanjutnya dilakukan penjelasan tentang posisi dan manfaat teknologi baru yang sebaiknya dilengkapi dengan demonstrasi teknologi.

- Jika teknologi baru merupakan teknologi yang pertama kali akan diadopsi maka perlu upaya penjelasan akan manfaat teknologi baru ke pengguna. Perlu dilengkapi dengan demonstrasi.

Upaya membangun persepsi positif pengguna terhadap kemudahan penggunaan teknologi. Upaya kedua adalah untuk membangun persepsi positif pengguna terhadap kemudahan penggunaan teknologi. Upaya ini merupakan upaya yang penting karena kegagalan pengembangan persepsi positif terhadap kemudahan penggunaan teknologi akan mempengaruhi integrasi teknologi. Upaya yang perlu dilakukan harus memperhatikan faktor penyebab dari persepsi kemudahan penggunaan teknologi.

- Faktor pertama yang berpusat pada teknologi itu sendiri biasanya disebabkan oleh pengalaman dalam menggunakan teknologi. Antara lain pengguna merasa kesulitan menggunakan teknologi jenis tersebut. Upaya yang dilakukan dapat dengan menyediakan teknologi yang user friendly dan pelatihan penggunaan yang intensif. Selain itu juga dengan menghadirkan teknologi tersebut kepada pengguna berdasarkan model aplikasi yang telah dipahami oleh pengguna. Contoh paling mudah adalah menghadirkan komputer dengan fasilitas aplikasi yang dilengkapi game dan pengguna dibiarkan berinteraksi dengan komputer tersebut sampai batas waktu tertentu sampai pengguna merasa familiar dengan komputer.

- Faktor penyebab kedua yaitu reputasi teknologi yang kurang baik didengar oleh pengguna. Upaya yang dapat dilakukan adalah menghadirkan teknologi ke pengguna dan memperbolehkan pengguna untuk berinteraksi dengan teknologi tersebut. Dengan catatan bahwa kekurangan yang didapatkan pengguna setiap saat langsung dilakukan langkah koreksi.

- Faktor penyebab ketiga yaitu mekanisme support. Solusi dari masalah ini adalah dengan menyediakan team support yang dapat membantu setiap saat serta menyediakan panduan penggunaan yang dapat diakses setiap saat dan memenuhi kebutuhan pengguna.

\section{UPAYA PEMBERDAYAAN MASYARAKAT MENUJU MASYARAKAT INFORMASI}

Upaya pemberdayaan yang dapat dilakukan fasilitator dalam pemberdayaan masyarakat menuju masyarakat informasi dapat dikelompokkan menjadi 2 upaya besar yaitu: upaya untuk membangun persepsi positif terhadap manfaat TIK dan upaya untuk membangun persepsi positif terhadap kemudahan/kesenangan menggunakan TIK.

- Upaya membangun persepsi positif masyarakat terhadap manfaat TIK terdiri dari upayaupaya sebagai berikut:

- Merubah paradigma maupun pola pikir masyarakat di era globalisasi ini yang bermuara pada tingginya nilai sebuah informasi sebagai sebuah faktor produksi penting maupun bahan baku dari pengetahuan yang berkualitas.

- Membawa masyarakat dengan kesadaran penuh untuk menggunakan TIK karena kemampuannya untuk memuaskan informasi yang menjadi kebutuhan masyarakat.

- Jika teknologi baru merupakan upgrade dari cara tradisional/teknologi lama maka melakukan upaya penjelasan bahwa cara tradisional/teknologi lama sudah tidak dapat memenuhi/mempercepat pencapaian kebutuhan. Selanjutnya dilakukan penjelasan tentang posisi dan manfaat teknologi baru yang sebaiknya dilengkapi dengan demonstrasi teknologi.

- Jika teknologi baru merupakan teknologi yang pertama kali akan diadopsi maka perlu upaya menjelaskan akan manfaat teknologi baru ke pengguna dan melengkapi dengan demonstrasi. 
- Upaya membangun persepsi positif masyarakat terhadap kemudahan dan kesenangan dalam penggunaan TIK, terdiri dari upaya-upaya sebagai berikut:

- Jika masyarakat merasa kesulitan menggunakan TIK maka perlu upaya pelatihan penggunaan TIK yang intensif dan menghadirkan TIK berdasarkan model aplikasi yang telah dipahami oleh pengguna. Contoh paling mudah adalah menghadirkan komputer dengan fasilitas aplikasi yang dilengkapi game dan masyarakat dibiarkan berinteraksi dengan komputer tersebut sampai batas waktu tertentu sampai pengguna merasa familiar dengan komputer.

- Jika masyarakat merasa reputasi TIK kurang baik maka perlu upaya menghadirkan TIK ke masyarakat dan memperbolehkan pengguna untuk berinteraksi dengan TIK tersebut.

- Jika masyarakat merasa kurangnya mekanisme dukungan dan layanan maka perlu upaya menyediakan team support yang dapat membantu setiap saat serta menyediakan layanan TIK.

Upaya pemberdayaan memberi landasan yang jelas untuk dukungan media komunikasi dan pelaksanaan pemberdayaan yang harus diambil fasilitator bilamana dihadapkan pada konteks yang berlaku di masyarakat.

\subsection{DUKUNGAN MEDIA KOMUNIKASI}

Media komunikasi bertujuan agar masyarakat dapat lebih mudah menerima dan memahami informasi dari fasilitator pemberdayaan. Dukungan media komunikasi berpengaruh dalam menumbuhkan persepsi positif masyarakat untuk mendayagunakan TIK. Suatu media bisa mencakup beberapa fungsi sekaligus, namun biasanya terdapat fungsi tertentu yang ditonjolkan.

- Media Motivasional. Media motivasional berfungsi menggugah perasaan dan mendorong masyarakat merefleksikan sikap-nilai hidupnya. Media motivasional menimbulkan semangat untuk bertindak dan memecahkan masalah yang terjadi dalam situasi nyata masyarakat. Media-media penyadaran diantaranya adalah:

- Poster. Poster dimaksudkan untuk menarik perhatian masyarakat akan manfaat positif TIK. Poster dapat dipasang di tempat-tempat strategis dan tempat yang direncanakan sebagai tempat pengoperasian MCAP.

- Film. Film yang dimaksud dalam hal ini adalah film yang berisikan cerita mengenai keberhasilan dan manfaat penggunaan TIK oleh masyarakat. Film dapat diputar untuk menggugah kesadaran masyarakat sekaligus sebagai media informasi dan pembelajaran (pengantar diskusi) mengenai hal khusus yang diperlukan oleh masyarakat.

- Komik. Komik adalah media grafis/cetak yang memadukan teks (tulisan) dengan gambar berdasarkan suatu alur cerita. Komik banyak digemari anak dan remaja karena informasinya mudah dicerna, dibawa dan disebarluaskan.

- Powerpoint. Powerpoint merupakan media presentasi yang dapat dikreasikan dengan bermacam warna, dilengkapi dengan foto-foto Qdan gambar digital. Powerpoint slide membantu fasilitator membuat ceramah menjadi lebih menarik dalam menginformasikan kemudahan dan manfaat pendayagunaan TIK.

- Layar dan proyektor. Layar dan proyektor dimaksudkan sebagai sarana untuk menyaksikan tayangan yang disiapkan. Dengan media ini, masyarakat secara bersamasama dapat menyaksikan tayangan yang ada.

- Media Instruksional. Media instruksional berfungsi memberikan informasi tahap demi tahap cara penggunaan TIK dan sesuatu yang terjadi jika tahapan diikuti. Media instruksional penggunaan TIK akan menimbulkan persepsi masyarakat terhadap kemudahan menggunakan TIK.

- Leaflet. Leaflet sangat efektif untuk menyampaikan pesan yang singkat dan mudah mengenai cara mendayagunakan TIK karena mudah disebarluaskan dan dapat dibawa pulang. Namun demikian, leaflet kurang tepat digunakan untuk masyarakat yang kemampuan membacanya terbatas.

- Powerpoint.

- Layar dan proyektor.

- Media Praktek/TIK. Media praktek/TIK berfungsi memberikan pengalaman pendayagunaan TIK bagi masyarakat. Media praktek/TIK akan menimbulkan persepsi masyarakat terhadap kemudahan dan manfaat mendayagunakan TIK.

- Perangkat keras (hardware) 
- Perangkat lunak (software)

- Jaringan akses informasi (netware)

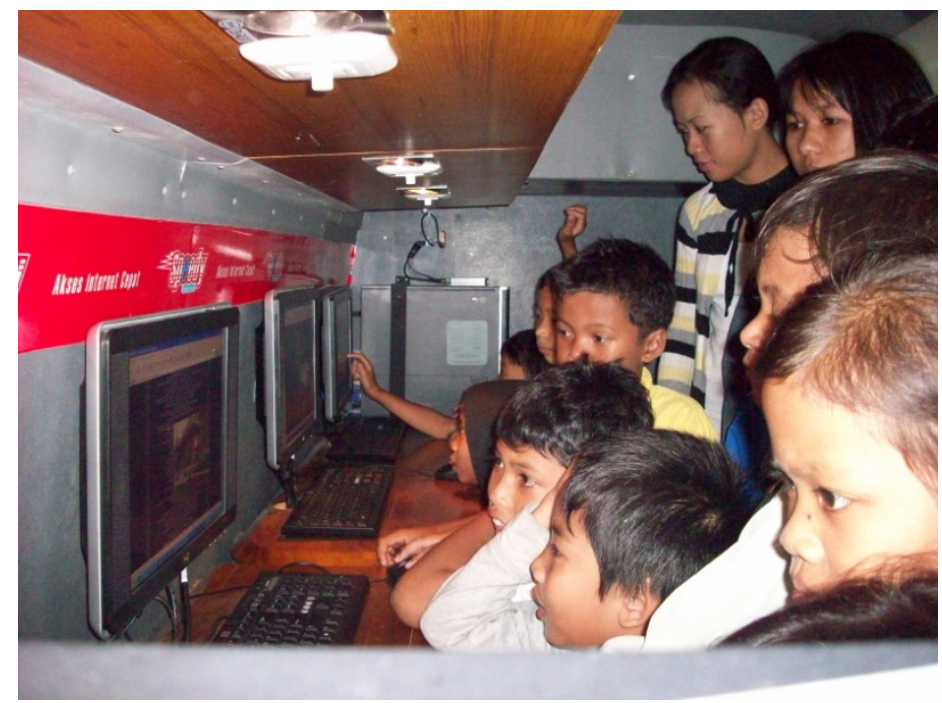

Gambar 2. Kesiapan Dukungan Media Praktek

\subsection{PELAKSANAAN PEMBERDAYAAN}

Dengan kesiapan dukungan media komunikasi maka pelaksanaan pemberdayaan masyarakat menuju masyarakat informasi dapat dimulai. Tahap pelaksanaan pemberdayaan masyarakat meliputi keseluruhan aktivitas yang dilaksanakan fasilitator bersama masyarakat. Beberapa aktivitas yang dilaksanakan fasilitator bersama masyarakat, yaitu:

- Membangun pemihakan. Pemihakan oleh fasilitator bertujuan menjadi landasan pemberdayaan yang sesuai aspirasi atau kebutuhan masyarakat. Fasilitator pemberdayaan melakukan diskusi bersama warga masyarakat guna mengumpulkan aspirasi dan membangun kesepakatan.

- Membangun persepsi positif masyarakat terhadap manfaat TIK. Dengan dukungan media penyadaran, fasilitator melaksanakan kegiatan-kegiatan:

- Fasilitator memberikan pemaparan. Upaya pemamparan ditujukan sebagai pemicu terjadinya kegiatan yang partisipatif. Pemaparan dilakukan interaktif dengan melibatkan masyarakat menceritakan masalah, kebutuhan dan potensi informasi yang dialami. Selanjutnya fasilitator menanggapi atau membandingkan manfaat dan kemudahan pendayagunaan TIK.

- memberi penayangan/pembagian media penyadaran disertai penjelasan keampuhan TIK untuk memenuhi kebutuhan informasi yang sesuai situasi nyata yang mereka alami.

- menayangkan cerita sukses yang menggugah masyarakat akan manfaat penggunaan TIK untuk meningkatkan produktivitas, kinerja dan efisiensi proses.

- Fasilitator mendemonstrasikan pendayagunaan TIK Upaya pemeragaan digunakan untuk membelajarkan masyarakat dengan cara memperlihatkan atau memperagakan manfaat dan langkah-langkah pedayagunaan TIK.

- melontarkan pertanyaan kunci yang bersifat refleksi sikap-nilai/renungan terhadap masalah, kebutuhan dan potensi informasi di masyarakat.

- mendemonstrasikan pendayagunaan TIK untuk menjawab masalah, kebutuhan dan potensi informasi di masyarakat.

- Fasilitator melakukan curah pendapat Upaya curah pendapat digunakan untuk menghimpun gagasan, pendapat, informasi, pengetahuan, pengalaman dari semua masyarakat terhadap pendayagunaan TIK.

- melontarkan pertanyaan kunci yang bersifat refleksi sikap-nilai (renungan) mengenai manfaat penting/menarik dari pendayagunaan TIK.

- bersama masyarakat menarik pelajaran dan melakukan perenungan bersama terhadap manfaat teknologi. 
- Membangun persepsi positif masyarakat terhadap kemudahan dan kesenangan dalam menggunakan TIK. Dengan dukungan media instruksional, fasilitator melaksanakan kegiatan-kegiatan:

- Fasilitator memberikan pemaparan Upaya pemamparan ditujukan sebagai pemicu terjadinya kegiatan yang partisipatif. Pemaparan dilakukan interaktif dengan melibatkan masyarakat menceritakan masalah, kebutuhan dan potensi informasi yang dialami. Selanjutnya fasilitator menanggapi atau membandingkan manfaat dan kemudahan pendayagunaan TIK.

- memberi penayangan/pembagian media instruksional dalam rangka mengajarkan masyarakat penggunaan teknologi yang mudah dan menyenangkan

- menayangkan rekaman penggunaan TIK di MCAP dalam rangka menggugah masyarakat akan kemudahan dan kesenangan menggunakan TIK.

- Fasilitator mendemonstrasi penggunaan TIK Upaya pemeragaan digunakan untuk membelajarkan masyarakat dengan cara memperlihatkan atau memperagakan manfaat dan langkah-langkah pedayagunaan TIK.

meminta wakil masyarakat yang bersedia mendemonstrasikan pendayagunaan TIK dengan dibimbing oleh fasilitator.

- menjelaskan tujuan praktek, langkah dan berbagai perangkat TIK yang akan digunakan.

- Fasilitator melakukan curah pendapat Upaya curah pendapat digunakan untuk menghimpun gagasan, pendapat, informasi, pengetahuan, pengalaman dari semua masyarakat terhadap pendayagunaan TIK .

- $\quad$ melontarkan pertanyaan kunci yang bersifat refleksi sikap-nilai (renungan) mengenai kemudahan dalam penggunaan teknologi kepada seluruh masyarakat.

- bersama masyarakat menarik pelajaran dan melakukan perenungan bersama.

- Fasilitator mengajak masyarakat secara bergantian untuk mempraktekan pendayagunaan TIK di MCAP

- Fasilitator mengoperasikan media hiburan bagi sebagian masyarakat yang menunggu di balai pertemuan.

Memberikan pengalaman pendayagunaan TIK bagi masyarakat. Dengan dukungan media praktek, fasilitator melaksanakan kegiatan-kegiatan:

- Fasilitator melakukan pendampingan Upaya pendampingan bertujuan untuk melatih dan meningkatkan kesadaran dan kemampuan masyarakat dalam mendayagunakan TIK. Pendampingan memberikan pengalaman nyata yang diperoleh bisa langsung dirasakan oleh masyarakat.

- melontarkan pertanyaan kunci yang bersifat refleksi sikap-nilai/renungan terhadap masalah, kebutuhan dan potensi informasi bagi praktikan.

- mempersilahkan praktikan mempraktekan pendayagunaan TIK

- mendampingi praktikan dengan menjelaskan tujuan praktek, langkah dan berbagai perangkat TIK yang digunakan.

- Fasilitator melakukan curah pendapat Upaya curah pendapat digunakan untuk menghimpun gagasan, pendapat, informasi, pengetahuan, pengalaman dari semua masyarakat terhadap pendayagunaan TIK .

- melontarkan pertanyaan kunci yang bersifat refleksi sikap-nilai (renungan) mengenai pengalaman pendayagunaan TIK

- bersama praktikan menarik pelajaran dan melakukan perenungan bersama.

- Memberikan layanan TIK bagi masyarakat. Dengan dukungan media praktek, fasilitator melaksanakan kegiatan-kegiatan:

- Fasilitator melakukan pelayanan Upaya pelayanan bertujuan untuk memberikan layanan manfaat TIK oleh fasilitator infomobilisasi.

- melontarkan pertanyaan kunci yang bersifat refleksi sikap-nilai/renungan terhadap masalah, kebutuhan dan potensi informasi bagi masyarakat.

- memberikan layanan informasi dan komunikasi sesuai masalah, kebutuhan dan potensi informasi bagi masyarakat. Layanan ini meliputi: pencarian informasi sesuai permintaan masyarakat melalui fasilitas internet, lalu disampaikan secara lisan maupun tulisan/tercetak. 


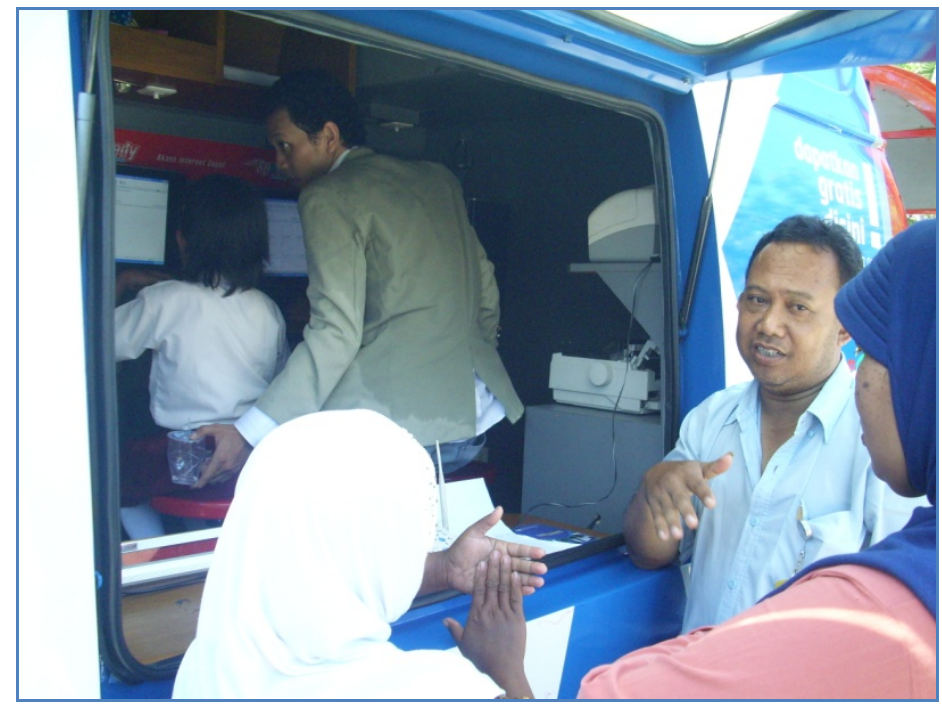

Gambar 3. Fasilitator Melaksanakan Pembedayaan

\section{PENUTUP}

Setelah melakukan kajian konsep dasar, tahapan pengembangan, dan melakukan pengamatan implementasi pengembangan technology acceptance model (TAM) dalam rangka pelaksanaan pemberdayaan masyarakat menuju masyarakat informasi, upaya pemberdayaan memberi landasan secara jelas dukungan media komunikasi dan pelaksanaan pemberdayaan. Upaya pemberdayaan yang dapat dilakukan fasilitator dalam pemberdayaan masyarakat menuju masyarakat informasi dapat dikelompokkan menjadi 2 upaya besar yaitu: upaya untuk membangun persepsi positif terhadap manfaat TIK dan upaya untuk membangun persepsi positif terhadap kemudahan/kesenangan menggunakan TIK.

\section{DAFTAR PUSTAKA}

Kadiman, Kusmayanto. 2006. Penelitian, Pengembangan dan Penerapan IImu Pengetahuan dan Teknologi Bidang Teknologi Informasi dan Komunikasi Tahun 2005-2025. Jakarta: Kementrian Negara Riset dan Teknologi Republik Indonesia.

Polyviou, Zachos A. 2007. The Information Society: Advantages and Disadvantages. Cyprus: University of Wales.

Sharma, Ravi; \& Mokhtar, Intan Azura. 2005. Bridging the Digital Divide in Asia. Australia: International Journal of Technology, Knowledge and Society.

Wijaya, Stevanus Wisnu. 2006. Kajian Teoritis Technology Acceptance Model Sebagai Model Pendekatan Untuk Menentukan Strategi Mendorong Kemauan Pengguna Dalam Menggunakan Teknologi Informasi dan Komunikasi. Prosiding Konferensi Nasional Sistem Informasi. Yogyakarta.

Wrihatnolo, Randy R; \& Dwidjowijoto, Riant Nugroho. 2007. Manajemen Pemberdayaan. Jakarta: PT Elex Media Komputindo. 